Григорій Капосльоз, кандидат психологічних наук, старший науковий співробітник,

ORCID ID 0000-0001-7369-3977 Національний університет оборони України імені Івана Черняховського

\title{
ПРОБЛЕМНІ ПИТАННЯ ОРГАНІЗАЦІЇ НАУКОВИХ ДОСЛІДЖЕНЬ В ІНТЕРЕСАХ НАВЧАЛЬНИХ ЗАКЛАДІВ ТА ОРГАНІВ УПРАВЛІННЯ ОСВІТОЮ У ЗБРОЙНИХ СИЛАХ УКРАЇНИ
}

У статті визначено деякі проблемні питання організації наукових досліджень для забезпечення освітньої діяльності вищого військового навчального закладу та функиіонування органів управління військовою освітою Украӥни. Проведено диференціацію недоліків існуючої моделі організації наукових досліджень за групами проблемних питань: нормативно-правового регулювання відносини у процесі організації наукових досліджень в інтересах військової освіти Украӥни; науково-методичного забезпечення організаиії наукових досліджень в інтересах військової освіти Украӥни; управління (замовлення, організачії, приймання, впровадження) науковими дослідженнями в інтересах військової освіти Украӥни; ресурсного забезпечення наукових досліджень в інтересах військової освіти Украӥни.

Ключові слова: вищий військовий навчальний заклад; військова освіта; організація наукових досліджень; освітня діяльність.

Постановка проблеми в загальному вигляді. На результативність функціонування системи військової освіти впливає низка зовнішніх i внутрішніх чинників в економічній, політичній, соціальній та інших сферах. Тому, цілком логічно, виникають потреби у диференціюванні пріоритетів політики, уточненні кола суб'єктів й об'єктів, їх ієрархії та функцій в системі військової освіти в конкретних умовах їі функціонування. Окрім того, організація сучасного освітнього процесу у військових навчальних закладах потребує розроблення та використання нових технологій навчання та виховання, якісної навчально-методичної літератури, тренажно-моделюючих засобів. Це надважливі завдання, які потребують проведення теоретичних та емпіричних досліджень 3 метою пошуку шляхів розв'язання проблем i суперечностей, які існують чи можуть виникнути.

Логіка побудови перспективної моделі організації наукових досліджень для забезпечення функціонування та розвитку системи військової освіти передбачає проведення аналізу проблем функціонування існуючої моделі організації наукових досліджень в інтересах навчальних закладів та органів управління освітою у Збройних Силах України.

Аналіз останніх досліджень і публікацій показує, що проблеми організації наукових досліджень в інтересах навчальних закладів розглядаються під час: 
визначення та обгрунтування механізмів державного управління удосконаленням наукової діяльності вищих навчальних закладів України на основі позитивного зарубіжного досвіду $[1,2]$;

аналізу законодавчої основи системи освітніх та наукових процесів в Україні та світі [3].

При цьому піднімаються проблемні питання:

залучення студентів до наукової i науково-дослідної роботи (популяризації наукового світогляду серед населення та наукового пошуку серед школярів і студентства);

заохочення відомих науковців до участі в навчальному процесі;

підвищення ефективності системи управління галуззю в усіх іiі субсистемах, на всіх управлінських рівнях (необхідність посилення державної науково-технічної політики в Україні та їі впливу на ефективність університетської науки, сприяння науковій діяльності вищих навчальних закладів, зміни позиції чиновників і громадськості в усвідомленні ролі науки у вищій школі в Україні, усунення розриву між розробленими на інноваційних засадах правовими механізмами та неспроможністю їх адекватної реалізації в умовах реформування галузі);

фінансового забезпечення галузі (неузгодженість прагнення реалізувати потужні реформаторські інтенції та умов державного фінансування, недосконалість правового поля використання альтернативних джерел фінансування);

активізації професійних взаємозв'язків між університетами, підприємницькими структурами (потенційними замовниками).

Хоча проблемні питання організації наукових досліджень в інтересах вищих військових навчальних закладів України уже частково аналізувалися [4], завдання залишається актуальним.

Мета статті полягає у визначенні та систематизації проблемних питань організації наукових досліджень в інтересах вищих військових навчальних закладів України.

\section{Виклад основного матеріалу.}

За допомогою методів аналізу та синтезу власних та сторонніх експертних оцінок стану організації наукових досліджень в інтересах вищих військових навчальних закладів України автором статті визначено недоліки існуючої моделі організації наукових досліджень в інтересах військової освіти України. Застосування системного підходу дозволяє визначити наступні чинники, що впливають на ефективність організації наукових досліджень в інтересах вищих військових навчальних закладів України, а caмe:

чіткість нормативно-правового регулювання відносини у процесі організації наукових досліджень в інтересах військової освіти України;

доступність та зрозумілість науково-методичного забезпечення організації наукових досліджень в інтересах військової освіти України; 
ефективність процедур управління науковими дослідженнями в інтересах військової освіти України;

достатність ресурсного забезпечення наукових досліджень в інтересах військової освіти України.

На думку автора, до недоліків у сфері нормативно-правового регулювання відносини у процесі організації наукових досліджень в інтересах військової освіти України, доцільно віднести:

1) відсутність у нормативно-правових актах Украӥни опису механізмів організащї наукових досліджень в інтересах освіти України, а caмe:

відповідно до Закону України "Про наукову i науково-технічну діяльність" наукова і науково-технічна діяльність (ННТД) у закладах вищої освіти (ЗВО) є невід’ ємною складовою освітньої діяльності і провадиться 3 метою інтеграції наукової, освітньої і виробничої діяльності в системі вищої освіти. Тобто, визначається лише важливість організації взаємного включення (взаємодії) сфер науки, освіти та виробництва;

поняття "наукове ... забезпечення освіти, поряд із терміном методичне забезпечення вживається у статті 75 Закону України "Про освіту" від 5 вересня 2017 року № 2145 - VIII. Проте, відсутні відповіді на запитання: “Яким чином здійснюється наукове забезпечення? зокрема, і системи військової освіти; "Яка частка та роль науки у науково-методичному забезпеченні?;

у Постанові Кабінету Міністрів України від 25 серпня 2004 р. № 1084 (зі змінами) "Про затвердження Порядку формування і виконання замовлення на проведення фундаментальних наукових досліджень, прикладних наукових досліджень та виконання науково-технічних (експериментальних) розробок за рахунок коштів державного бюджету, хоча і є вимога здійснювати наукове забезпечення усіх сфер діяльності, проте сам зміст (визначення) наукового забезпечення не наводиться, механізми не розглядаються;

у нормативних актах України відсутній розподіл відповідальності та повноважень щодо управління програмами, не розкрито специфіку організації і виконання наукових частин програм, зокрема, в галузі освіти;

положення Концепції військової освіти в Україні [5], які визначали заходи щодо організації наукових досліджень не виконанні а продовження їх виконання $\epsilon$ недоречним у зв'язку із прагненням України впроваджувати досвід ЄС та НАТО щодо організації освіти та наукових досліджень;

2) відсутність у нормативно-правових актах Міністерства оборони України положень щзодо організації наукових досліджень в інтересах військової освіти Украӥни, наприклад:

у Положенні про організацію наукової та науково-технічної діяльності в Збройних Силах України, затверджено наказом Міністерства оборони України від 27.07.2016 № 385 [6] відсутнє згадування про освіту взагалі і освітній процес зокрема (можливо, це і недоречно у даному наказі?). Проте, інший документ який би врегульовував це питання відсутній. 
Якщо припустити, що достатньо й існуючого наказу, то є низка запитань до його змісту. У наказі зроблено акцент на адмініструванні документообігу під час організації наукових досліджень (науково-дослідних, дослідноконструкторських робіт (НДДКР) та оперативних завдань). Питання визначення проблеми, організації наукового пошуку в даному документі не розкриті, хоча і передбачені ДСТУ 3973-2000 "Система розроблення та поставлення продукції на виробництво. Правила виконання науководослідних робіт. Загальні положення. У зазначеному документі, також не розглядається порядок організації інших видів наукових досліджень та науково-технічних (експериментальних) розробок, а саме: розроблення монографій, енциклопедій і словників, порадників, підручників, методичних посібників, дисертацій, статей, доповідей, звітів про результати досліджень на навчаннях, рецензій, відзивів, висновків, тощо, - які більш характерні для ННТД науково-педагогічних працівників ніж НДДКР.

До недоліків науково-методичного забезпечення організації наукових досліджень в інтересах військової освіти України, доцільно віднести:

1) відсутність у науково-методичних виданнях Міністерства оборони України положень щэодо організації наукових досліджень в інтересах військової освіти Украӥни, а саме: у єдиному науковометодичному документі, який визначає особливості організації наукових досліджень у ЗС України, - методичний посібник "Політика і процес замовлення воєнно-наукової продукції, організації та виконання науководослідних робіт”, затверджений Міністром оборони України 17.04.2000, особливості організації наукових досліджень в інтересах військової освіти не розглядаються. Окрім того, використання посібника ускладнено тим, що низка його положень не відповідає (суперечить) останній редакції (наказ МО Українни № 385 від 27.07.2016р.) Положення про організацію наукової і науково-технічної діяльності у Збройних Силах України [6];

у нормативно-правових [7] документах, які визначають організацію наукової та науково-технічної діяльності у ВВНЗ питання організації наукових досліджень в інтересах ВВН3 не висвітлено. Методичні рекомендації з цих питань відсутні;

2) нормативно не закріплені об’єктивні критерії та відповідний порядок оцінювання діяльності наукових і науково-педагогічних працівників, результативності наукових досліджень, які ними провадяться, наприклад:

в Україні [8] та в Міністерстві оборони України [9, 10] розроблено науково-методичний апарат, який дозволяє здійснювати державну атестацію, перевірку, вивчати стан справ у вищих навчальних закладах (ВНЗ) як правило шляхом оцінювання ефективності наукової діяльності ВН3 взагалі: організація та результати. Окрім того, у кожному вищому військовому навчальному закладі розроблено, відповідним порядком затверджено та застосовується методика або навіть комплекс методик оцінювання наукової та науково-технічної діяльності наукових та науково-педагогічних працівників ВВНЗ [11]. 
Проте, результативність наукових досліджень в інтересах вищої військової освіти України, у кращому випадку, оцінюється за шкалою “впроваджено / не впроваджено (за наявністю актів впровадження). Оскільки відповідальність за реалізацію результатів наукових досліджень покладається на їх замовника, то неспроможність або небажання останнього замовляти актуальні дослідження чи (та) впроваджувати отримані наукові результати визначає низьку результативність діяльності виконавців наукових досліджень;

3) відсутні науково-методичні матеріали, які б розкривали прочедури переходу вітчизняної системи організачії наукових досліджень до стандартів краӥн, членів НАТО.

До проблемних питань управління науковими дослідженнями в інтересах військової освіти України, необхідно віднести:

1) відсутність изільової настанови щэодо впровадження інноваційних технологій управління науковими дослідженнями, щзо замовляються та проводяться в інтересах Збройних Сил України, що проявлясться у:

істотному розриві між розробленими на інноваційних засадах правовими нормами організації ННТД, діяльності вищої школи України та неспроможністю їх адекватної реалізації в умовах військової освіти та науки, яке на практиці значною мірою має ознаки не концептуальних змін, а ситуативних кроків 3 метою пристосування нормативної бази Міністерства оборони без зміни існуючої системи організації досліджень;

небажанні підприємств ОПК, за рідким виключенням, вкладати частину прибутку в розвиток наукової та інноваційної діяльності ВВНЗ, сприяти вдосконаленню навчально-матеріальної бази;

недостатньому престижі наукової і науково-технічної діяльності серед молоді, який пояснюється тим, що виключно науковими досягненнями в нашій країні дуже важко досягти таких матеріальних ознак успішної людини, як престижна машина, кількаповерховий будинок тощо;

відсутності соціально-економічних, організаційних, правових умов для формування та ефективного використання наукового та науково-технічного потенціалу слухачів, курсантів і студентів ВВНЗ. Зокрема, діяльність курсантів суворо регламентована розпорядком дня та розкладом занять. При цьому, сьогодні якщо фізичній підготовці відводиться, як правило, 12 годин на тиждень (ранкова фізична зарядка, спортивно-масова робота, планові заняття 3 фізичної підготовки та спортивні свята), то роботі в наукових гуртках $-2,5$ години на тиждень;

відсутності соціально-економічних, організаційних, правових умов для формування та ефективного використання наукового та науково-технічного потенціалу викладачів ВBН3. Значне навчальне навантаження на науковопедагогічних працівників не дозволяе їм приділяти достатньо уваги науковій роботі (у тому числі розробленню тренажерної апаратури). Наказом Міністерства оборони України "Про особливості організації освітнього процесу у вищих військових навчальних закладах та військових навчальних 
підрозділах вищих навчальних закладів у 2016-2017 навчальному році” від 19.08.2016 № 432 встановлено максимальне навантаження науковопедагогічним працівникам ВВНЗ і військових навчальних підрозділів вищих навчальних закладів у 2016-2017 навчальному році 750 годин;

2) недосконалі механізми замовлення та планування наукових досліджень в інтересах системи військової освіти взагалі та ВВНЗ зокрема, а саме:

відсутні дієві механізми лобіювання наукових досліджень в інтересах ВВНЗ у ВНУ ГШ ЗС України під час короткострокового планування наукової і науково-технічної діяльності у Збройних Силах України. Заявки (ТК) на виконання НДР ВВНЗ важко погоджуються із Воєнно-науковим управлінням (ВНУ) ГШ ЗС України [6], для якого питання удосконалення військової освіти, розвитку ВВНЗ не є профільними та пріоритетними [12]);

середньострокове планування наукової та науково-технічної діяльності у Збройних Силах України здійснюється без врахування потреб освітнього процесу та розвитку ВВНЗ. Поодинокі дослідження виконуються на перекір існуючій системі завдяки зусиллям ДВОНСтаГП під час замовлення деяких досліджень в інтересах ВВНЗ. Аналізуючи терміни введення в дію сучасного законодавства в питаннях вищої освіти та науки а також значну кількість проблемних питань, що при цьому виникли, дослідники [3, с. 60] прийшли до висновку, що державне управління повинно орієнтуватися насамперед на середньо- та довгострокову перспективу, на здійснення структурних зрушень i технологічне відновлення, тоді ринкові механізми встигнуть адекватно відреагувати на зміни, та ситуацію в державі в цілому, у достатній мірі їх задовольняти і сприяти досягненню поставлених цілей;

планування наукової та науково-технічної діяльності наукових центрів ВВНЗ здійснюється без врахування потреб освітнього процесу. Частково це було пов'язано із антитерористичною операцією в Донецькій та Луганській областях України та пріоритетом замовників наукової (науково-технічної) продукції на забезпечення бойових дій військ (сил);

не визначено, який відсоток наукового потенціалу ВВНЗ його начальник має право використати для проведення наукових досліджень в інтересах забезпечення функціонування та розвитку закладу (фактично це відбувається за остаточним принципом);

не визначено відповідальність та повноваження науково-організаційних підрозділів ВВНЗ у процесі замовлення НДР. У багатьох випадках ці підрозділи виконують завдання лише щодо узагальнення поданих кафедрами та науковими підрозділами пропозицій, їх погодження із ВНУ ГШ ЗС України;

кафедри відіграють виключно допоміжну (по відношенню до наукових підрозділів ВВНЗ) роль у процесі замовлення та виконання НДР;

3) Наявні також $i$ загальні проблеми організації наукових досліджень, що не можуть не впливати на ефективність проведення наукових досліджень в інтересах системи військової освіти, а саме: 
відсутні чіткі підходи оцінювання наукових досліджень (замовлення, ходу виконання, наукових результатів);

у зв'язку з широким використанням мережі інтернет втрачено навички організації інформаційного забезпечення наукових досліджень;

не розроблено прозорі механізми фінансування наукових досліджень в інтересах військової освіти України, що дозволяли б диверсифікувати джерела надходження коштів на їх проведення;

термін «науковий» проект вживається безвідносно до реального застосування технології управління проектами, що вказує на нерозуміння переваг цієї технології та вимог, які вона висуває до організації наукового дослідження. Не реалізуються підвищені вимоги до виконання наукових проектів (йдеться про моніторинг їх виконання, оцінку результативності);

неврегульовано питання контролю над передачею наукових досягнень, «відкритості» у взаємодії наукового співтовариства. Ще зовсім недавно багато американських експертів говорили про те, що подібний контроль $\epsilon$ проблемою для інтеграції науки i обмежує рух до науково-технічних досягнень і прогресу, в тому числі і в США.

До проблемних питань ресурсного забезпечення наукових досліджень в інтересах військової освіти України, необхідно віднести:

1) відсутність цільового фінансування та матеріального забезпечення прикладних та пошукових досліджень, не кажучи вже про фундаментальні дослідження. Цей фактор особливо актуальний при розробленні напівнатурних тренажерів, у яких органи управління та відображення інформації повністю ідентичні зразкам озброєння і військової техніки. Проте лише тренажери даного типу дозволяють розвинути та закріпити так звану моторну пам'ять, довести навички роботи 3 апаратурою до автоматизму [12];

2) застаріла навчально-матеріальна база курсантських конструкторських бюро,відсутність фінансування винахідницької та рачіоналізаторської роботи. Наприклад, у багатьох випадках курсанти, студенти та викладачі змушені за власні кошти купувати радіодеталі та елементи технічних пристроїв, щоб займатись реалізацією своїх наукових розробок [12];

3) відсутність наукового потенціалу в тому числі $і$ людського. Сьогодні, на думку більшості західних експертів, при відсутності наукового потенціалу в тому числі і людського, говорити про безпеку держави - марно [13, с. 20]. В процесі реалізації наукових і науково-технічних програм не вистачає спеціалістів з програмно-цільового управління;

4) не реалізовано заходи реалізації Концепиії військової освіти в Україні [5] щодо створення, на базі Академії Збройних Сил України, Науково-методичного центру розроблення методології науково-теоретичних досліджень, освітніх технологій, моделей, програм реформування та розвитку військової освіти, а також розроблення програми пріоритетних науково-дослідних робіт з проблем вищої військової школи. 
Висновки. Недоліки існуючої моделі організації наукових досліджень в інтересах військової освіти України доцільно розглянути за групами проблемних питань:

нормативно-правового регулювання відносини у процесі організації наукових досліджень в інтересах військової освіти України;

науково-методичного забезпечення організації наукових досліджень в інтересах військової освіти України;

управління науковими дослідженнями в інтересах військової освіти України;

ресурсного забезпечення наукових досліджень в інтересах військової освіти України.

Існуючі недоліки знижують якість та ефективність як системи організації наукових досліджень у ВВН3, так i мотивацію наукових працівників на впровадження результатів власних наукових досліджень в освітній процес ВВНЗ.

На пошук шляхів та способів вирішення проблемних питань будуть спрямовані зусилля під час наступних досліджень.

\section{ЛІТЕРАТУРА}

1. Ясниська Н. Деякі аспекти державного управління наукової діяльністю вищих навчальних закладів в умовах реформування галузі [Електронний ресурс] / Н. Ясниська // Науковий вісник. - 2015/2016. - Вип. 16/17 “Демократичне врядування”. - Режим доступу : vivacademy.com/vidavnitstvo_1/visnyk16/fail/Jasnyska.pdf.

2. Hendricks Cher C. Improving Schools Through Action Research: A Comprehensive Guidefor Educators [Text] / Cher C. Hendricks. - 2nd Edition. - Boston : Pearson, 2009. $224 \mathrm{p}$.

3. Ніколаєнко С. Сучасна законодавча основа в системі майбутніх освітнього та наукових процесів в Україні і світі / С. Ніколаєнко // Вища школа. - 2003. - 4-5. - С. 3-19.

4. Модель перспективної системи наукового забезпечення функціонування та розвитку військової освіти: Звіт про науково-дослідну роботу шифр "Концепція НЗ (проміжний). - К.: НУОУ, 2017. - 283 с.

5. Постанова Кабінету Міністрів України від 15 грудня 1997 року № 1410 "Про створення єдиної системи військової освіти" [Електронний ресурс]. - Режим доступу : http://zakon0.rada.gov.ua/laws/show/1410-97-\%D0\%BF

6. Положення про організацію наукової та науково-технічної діяльності в Збройних Силах України, затверджено наказом Міністерства оборони України від 27.07.2016 № 385 [Електронний ресурс]. - Режим доступу : http://zakon0.rada.gov.ua/laws/show/z1172-16

7. Наказ начальника Національного університету оборони України імені Івана Черняховського "Про організацію оцінки впровадження результатів науково-дослідних (дослідно-конструкторських) робіт у навчальний процес та наукову і науково-технічну діяльність університету $\square$ від 20 вересня 2017 року № $250 .-2$ c.

8. Положення про проведення державної атестації вищих навчальних закладів III-IV рівнів акредитації Міністерства освіти і науки України у частині наукової, науковотехнічної та інноваційної діяльності / Затверджено Наказом Міністерства освіти і науки України 30.03.2010 р. № 277. - 9 с.

9. Інструкція про організацію підготовки та проведення інспекційних заходів / Затверджена наказом Міністра оборони України від 21 липня 2011 р. №440. - К. : Міністерство оборони України, 2011.- 43 с. 
10. Методика комплексної (поточної, часткової) перевірки, вивчення стану справ у вищих військових навчальних закладах та військових навчальних підрозділах вищих навчальних закладів / Затверджена наказом Міністра оборони України від 8 вересня 2014 p. №630. - К. : Міністерство оборони України, 2014. - 111 с

11. Дослідження шляхів підвищення ефективності наукової та науково-технічної діяльності у Збройних Силах України : звіт про складову частину НДР шифр “Структура НДУ” (заключний) / Науковий центр бойового застосування Сухопутних військ. - Одеса : Військова Академія, 2012. - 221 с

12. Організація наукових досліджень у вищих навчальних закладах технічного профілю : звіт про складову частину НДР шифр “Концепція НЗ” (остаточний) / Житомирський військовий інститут імені С. П. Корольова. - Житомир: ЖВІ., 2017. - 57 с.

13. Організація наукових досліджень в інтересах вищих військових навчальних закладів сухопутних військ збройних сил України: : звіт про складову частину НДР шифр "Концепція Н3" (остаточний) / Національна академія сухопутних військ імені гетьмана Петра Сагайдачного. - Львів: НАСВ, 2017. - 110 с.

\section{REFERENCES}

1. Yasnys'ka, N. (2016). Deyaki aspekty derzhavnoho upravlinnya naukovoyi diyal'nistyu vyshchykh navchal'nykh zakladiv v umovakh reformuvannya haluzi [Some Aspects of Public Management of Scientific Activities of Higher Educational Institutions in the Reform of the Industry]. Naukovyy visnyk. - 2015/2016. - Vyp. 16/17 "Demokratychne vryaduvannya". Rezhym dostupu : vivacademy.com/vidavnitstvo_1/visnyk16/fail/Jasnyska.pdf. (in Ukrainian).

2. Hendricks Cher, C. (2009). Improving Schools Through Action Research: A Comprehensive Guidefor Educators. 2nd Edition. Boston : Pearson, 224.

3. Nikolayenko, S. (2003). Suchasna zakonodavcha osnova v systemi maybutnikh osvitn'oho ta naukovykh protsesiv v Ukrayini i sviti [Modern Legislative Framework in the System of Future Educational and Scientific Processes in Ukraine and the World]. Vyshcha shkola, 3-19. (in Ukrainian).

4. Model' perspektyvnoyi systemy naukovoho zabezpechennya funktsionuvannya ta rozvytku viys'kovoyi osvity: Zvit pro naukovo-doslidnu robotu shyfr "Kontseptsiya NZ (promizhnyy) [Model of the perspective system of scientific support for the functioning and development of military education: Report on research work cipher "Concept NZ" (intermediate)] (2017). K.: NUOU, 283. (in Ukrainian).

5. Postanova Kabinetu Ministriv Ukrayiny vid 15 hrudnya 1997 roku № 1410 "Pro stvorennya yedynoyi systemy viys'kovoyi osvity" [Resolution of the Cabinet of Ministers of Ukraine of December 15, 1997, №. 1410 "On the Establishment of a Unified Military Education System"] (1997). Rezhym dostupu : http://zakon0.rada.gov.ua/laws/show/1410-97-\%D0\%BF (in Ukrainian).

6. Polozhennya pro orhanizatsiyu naukovoyi ta naukovo-tekhnichnoyi diyal $\square$ nosti v Zbroynykh Sylakh Ukrayiny, zatverdzheno nakazom Ministerstva oborony Ukrayiny vid 27.07.2016 № 385 [Regulations on the organization of scientific and scientific and technical activities in the Armed Forces of Ukraine, approved by the order of the Ministry of Defense of Ukraine dated 27.07.2016 №. 385] (2016). Rezhym dostupu : http://zakon0.rada.gov.ua/laws/show/z1172-16 (in Ukrainian).

7. Nakaz nachal'nyka Natsional'noho universytetu oborony Ukrayiny imeni Ivana Chernyakhovs'koho "Pro orhanizatsiyu otsinky vprovadzhennya rezul'tativ naukovo-doslidnykh (doslidno-konstruktors'kykh) robit u navchal'nyy protses ta naukovu i naukovo-tekhnichnu diyal $\square$ nist' universytetu' vid 20 veresnya 2017 roku № 250 [Order of the Head of the National University of Defense named Ivan Chernyakhovsky "On the organization of evaluation of the implementation of research (research and development) work in the educational process and scientific and scientific and technical activities of the University" from September 20, 2017, №. 250] (2017), 2. (in Ukrainian). 
8. Polozhennya pro provedennya derzhavnoyi atestatsiyi vyshchykh navchal'nykh zakladiv III-IV rivniv akredytatsiyi Ministerstva osvity i nauky Ukrayiny u chastyni naukovoyi, naukovotekhnichnoyi ta innovatsiynoyi diyal'nosti [Regulations on conducting state certification of higher education institutions of III-IV accreditation levels of the Ministry of Education and Science of Ukraine in the part of scientific, scientific-technical and innovation activity] (2010). (in Ukrainian).

9. Instruktsiya pro orhanizatsiyu pidhotovky ta provedennya inspektsiynykh zakhodiv [Instruction on the organization of preparation and conduct of inspection activities] (2011). K., Ministerstvo oborony Ukrayiny, 43. (in Ukrainian).

10. Metodyka kompleksnoyi (potochnoyi, chastkovoyi) perevirky, vyvchennya stanu sprav u vyshchykh viys'kovykh navchal'nykh zakladakh ta viys'kovykh navchal'nykh pidrozdilakh vyshchykh navchal'nykh zakladiv [Methodology of complex (current, partial) verification, study of the state of affairs in higher military educational institutions and military educational units of higher educational institutions] (2014). K., Ministerstvo oborony Ukrayiny, 111. (in Ukrainian).

11. Doslidzhennya shlyakhiv pidvyshchennya efektyvnosti naukovoyi ta naukovotekhnichnoyi diyal'nosti u Zbroynykh Sylakh Ukrayiny : zvit pro skladovu chastynu NDR shyfr "Struktura NDU" (zaklyuchnyy) [Investigation of ways to increase the efficiency of scientific and scientific and technical activities in the Armed Forces of Ukraine: Report on the component part of the GDR cipher "Structure of NDU" (final)] (2012). Viys'kova Akademiya, 221. (in Ukrainian).

12. Orhanizatsiya naukovykh doslidzhen' u vyshchykh navchal'nykh zakladakh tekhnichnoho profilyu : zvit pro skladovu chastynu NDR shyfr "Kontseptsiya NZ" (ostatochnyy) [Organization of scientific research in higher educational institutions of technical profile: report on the component part of the GDR cipher "Concept NS" (final)] (2017). Zhytomyr: ZHVI., 57. (in Ukrainian).

13. Orhanizatsiya naukovykh doslidzhen' $\mathrm{v}$ interesakh vyshchykh viys'kovykh navchal'nykh zakladiv sukhoputnykh viys'k zbroynykh syl Ukrayiny: zvit pro skladovu chastynu NDR shyfr "Kontseptsiya NZ" (ostatochnyy) [Organization of scientific research in the interests of higher military educational institutions Armed Forces of Ukraine: report on the research part of the code "concept DK '(final)] (2017). L'viv, NASV, 110. (in Ukrainian).

\title{
PEЗЮМЕ
}

\author{
Григорий Капослёз, \\ кандидат психологических наук, \\ старший научный сотрудник, \\ Национальный университет обороны Украины \\ имени Ивана Черняховского
}

\section{Проблемные вопросы организации научных исследований в интересах учебных заведений и органов управления образованием в Вооруженных Силах Украины}

В статье определены некоторые проблемные вопросы организации научных исследований для обеспечения образовательной деятельности высшего военного учебного заведения и функционирования органов управления военным образованием Украины. Проведено дифференциичию недостатков существующей модели организации научных исследований по группам проблемных вопросов: нормативно-правового регулирования отношения в прочессе организации научных исследований в интересах военного образования Украины; научно-методического обеспечения организации научных исследований в интересах военного образования Украины; управления (заказ, организации, принятия, внедрения) научныли исследованиями в интересах военного образования Украинь; ресурсного обеспечения научных исследований в интересах военного образования Украиньл. 
Ключевые слова: высшее военное учебное заведение; военное образование; организация научных исследований; образовательная деятельность.

\title{
SUMMARY
}

\author{
Grigoriy Kaposlyoz, \\ Candidate of Psychological Science, \\ senior researcher \\ National Defence University of Ukraine \\ named after Ivan Chernyakhovskyi
}

\section{Problematic issues in the organization of scientific research in the interest of educational institutions and education management institutions in the Armed Forces of Ukraine}

Introduction. To date, in the normative legal acts, scientific and methodological developments, scientific sources there is no list of problematic issues in organizing scientific research in the interests of higher military educational institutions and military education authorities of Ukraine, which does not allow to form an effective system of measures for its improvement.

Purpose. To identify and systematize the problematic issues of organization of scientific research in the interests of higher military educational institutions of Ukraine.

Methods. The method of analysis, synthesis and the method of expert evaluations are used.

Results. According to the results of an expert assessment of the state of organization of scientific research in the interests of military education of Ukraine, the problematic issues are proposed, which are proposed to be systematized in groups:

problematic issues of regulatory and legal regulation of relations in the process of organization of scientific research in the interests of military education of Ukraine;

problematic issues of scientific and methodological provision of organization of scientific research in the interests of military education of Ukraine;

problematic issues in the management of scientific research in the interests of military education of Ukraine;

problematic issues of resource support for scientific research in the interests of military education in Ukraine.

Originality. The problem issues of organization of scientific research in the interests of military education of Ukraine are specified and systematized.

Conclusion. The differentiation of problem issues in organizing scientific research in the interests of educational institutions and education management bodies in the Armed Forces of Ukraine is presented in the article as it is expedient to consider as directions of improvement of the system of organization of scientific researches in the interests of higher military educational institutions.

Key words: higher military educational institution; military education; organization of scientific research; educational activity. 